\title{
21. Unstable Bipartisanship or Off the Agenda? Social issues during the 2013 election campaign
}

\author{
Rob Manwaring, Gwen Gray and Lionel Orchard
}

\section{Introduction}

The 2013 federal election was dominated by economic issues, carbon policy and the controversies surrounding asylum seekers, driven by the Abbott Coalition's campaign to damage the economic and political credibility of the Rudd-Gillard governments. As a result, the role and place of social policy issues during the campaign was uncertain and had less prominence. With the exception of the issue of paid parental leave, traditional social policy issues such as education and health did not play a decisive and direct role in the outcome. In part, this was the result of a deliberate strategy by the Coalition to neutralise key social issues, often perceived as the ALP's traditional areas of strength (McAllister and Pietsch 2011: 19-20). Nevertheless, there was some social policy convergence between the two major party groupings but this was for tactical rather than ideological reasons.

This chapter offers a detailed analysis of the role of social policy during the election campaign, by setting out the broader context and then focusing on the key policy issues, including the paid parental leave (PPL) scheme, the Gonski reforms to secondary education, the National Disability Insurance Scheme (NDIS), health policy, indigenous policy and welfare policy.

Generally, the prominence of social policy issues at federal elections waxes and wanes over time. Like other policy domains, social policy is subject to Downs' 'issue attention cycle', where a confluence of fashion, events, and interests can combine to elevate some issues to the policy agenda while other issues receive less prominence (Downs 1972). For instance, industrial relations policy was a key factor at the 2007 election (Wanna 2010) but not in 2010 or 2013, largely because Abbott claimed WorkChoices was now 'dead, buried and cremated' (Karvelas 2010). Survey data tends to show that health and economic policies are the dominant issues for most people, although followed closely by education (Bean and McAllister 2012). Data from the 2013 Australian Election Study (AES) shows that health and education were the two key issues for voters, with over 60 per cent of respondents indicating that these were 'extremely important' 
issues for them (Bean et al. 2013; Figure 1 sets out the most important policy issues for respondents). Despite the importance of social services for citizens, Australia's federal system means that many of these services are delivered at the state level. This tempers their overall impact on voting behaviour at federal elections. Accordingly, in the political discourse of the 2013 campaign, social policy provided important 'atmospherics' but was not decisive in a governmentchanging election.

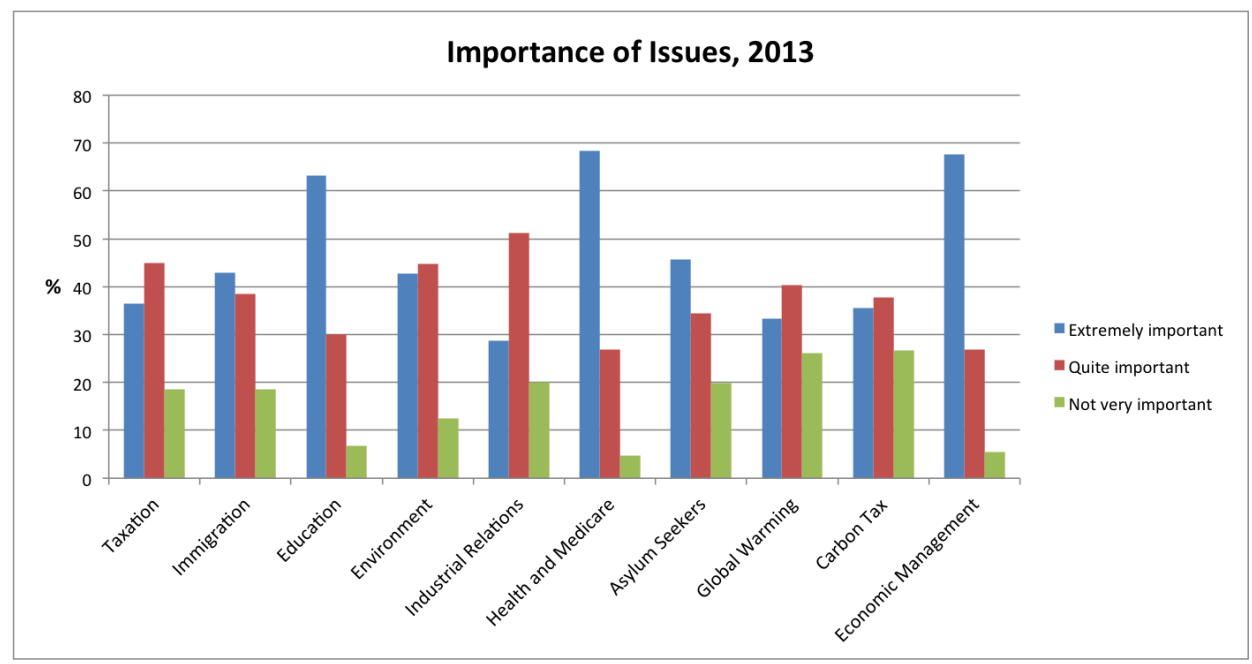

Figure 1: Importance of issues, 2013 Australian Election Study

Source: Bean et al. 2014.

Despite limited media coverage, social policy was a vexed issue for the major parties. For the ALP, the two most significant reforms were the NDIS, and the 'Better Schools Plan' - a commitment by Kevin Rudd to fund for six years a new school education formula based on the review by David Gonski. However, the ALP was tactically caught up in selling these policies in the face of the protracted leadership change. Kevin Rudd was hamstrung in promoting these two major reforms given that they had been introduced and implemented by his predecessor Julia Gillard. It is striking that in his acceptance speech, Rudd praised Gillard as a 'radical reformer' citing her main achievements as the Fair Work Act and the national education test reforms (introduced during his term as prime minister), but not her (prime ministerial) role in either the NDIS or Gonski reforms (ABC 2013). The issue for Rudd was how to consolidate these popular reforms and, at the same time, offer a new distinctive agenda. In part, his relabelling of what were commonly called the 'Gonski reforms' as the 'Better 
Schools Plan' reflected this dilemma. The other dilemma for Rudd was how to ensure that disaffected ALP supporters did not defect to the Greens-who generally claim to have a more progressive social policy agenda.

For the Coalition, social issues also raised a series of dilemmas. AES data shows that the public generally views the ALP as a better custodian of the health and education policy areas (McAllister and Pietsch 2011). Whilst clearly making an impact on the electorate with his strong economic message and his pledge to repeal the carbon tax, Opposition Leader Tony Abbott had to ensure that social policy did not damage his campaign. In this respect, Abbott's response was the so-called 'small target' strategy, pursuing policy convergence with the ALP, with the exception of the PPL scheme, where it sought to outflank Labor from the left. Abbott also advocated the need to refocus efforts in indigenous policy, albeit in an embryonic way. In this, Noel Pearson and his allies played a key advisory role.

\section{Schools education policy: Neutralising Gonski}

The political and policy debates about school education in Australia have always been riven by conflict between public and private priorities and interests. This continues to be so. Equity and social inclusion in education policy have proven to be difficult to achieve despite the strong reforming efforts of the Rudd-Gillard governments in this area. ${ }^{1}$ In 2007, education was a critical policy area for the newly installed Prime Minister, Kevin Rudd. Earlier, in the 2007 election campaign, he had promised an 'education revolution'. The lack of progress in transforming Australia's secondary education performance was a factor in portraying Rudd in his first term as PM as strong on symbolic policy (for example, the Apology to the Stolen Generations of Indigenous children and ratifying the Kyoto Protocol on carbon emissions) but less able to demonstrate substantive policy advances. Not without controversy and strongly shaped by advice from influential think tanks like the Grattan Institute (for commentary, see Ashenden 2013), the ALP's education achievements included introducing the National Assessment Program - Literacy and Numeracy (NAPLAN) tests and the My Education website (along with the subsequent perception that this was a 'backdoor' introduction of school league tables). By the time of Rudd's second tilt as prime minister, the 'Gonski' reforms were at the top of the Government's education policy agenda. In April 2010, Julia Gillard as Minister of Education commissioned businessman David Gonski to chair an expert panel on schools funding. Among its findings, the Gonski review highlighted declining educational outcomes for Australians, and suggested a new, simpler funding

1 For recent surveys, see Keating (2010); Watson and Liu (2014). 
model with increased funds from both state and federal governments (ABC 2012). Julia Gillard, as prime minister, attempted to make the Gonski reforms a centrepiece of her case for re-election. Initially, the Gonski reforms were met with resistance from the federal Opposition. Moreover, since most of the large states were also held by the Liberals, Gillard was struggling to persuade the state Liberals to sign up to the new funding agreements.

When Rudd assumed the prime ministership in June 2013, he sought to both consolidate this agenda and remake it as the 'Better Schools Improvement Plan'. At the outset of the campaign, only New South Wales under Barry O'Farrell had broken Liberal ranks to sign up to the new model, promising the state muchneeded additional funding. Deals with the Labor jurisdictions were brokered on the cusp of the election with the Tasmanian, Australian Capital Territory and South Australian governments.

The significant moment came on 2 August when the Abbott Coalition announced support for Rudd's 'Better Schools Plan' after all, but would only commit to funding for four rather than six years. Abbott described this as a 'unity ticket' with the Government. Labor sensed this was purely for narrow electoral reasons (AAP 2013a). Yet, the Coalition's reversal changed the dynamics of the debate. For Labor the pressure to sign up the major states increased, and eventually Victoria also agreed, albeit on somewhat different terms. The refusal of both Queensland and Western Australia to sign up meant this was only a limited achievement for the ALP.

The Coalition, by partially accepting the 'Better Schools Plan', also marginalised the ACTU's 'I give a Gonski' campaign, which the union movement hoped would have the same impact as its successful 2007 anti-WorkChoices campaign. Hence, the ALP lost its policy 'edge' on this issue. Nevertheless, the overall level of commitment by the Coalition to the Gonski agenda was open to question and indeed, post-election, its failed attempt to reverse its position suggested that tactical considerations outweighed any ideological ones in the context of the campaign.

Interestingly, the Coalition's policy U-turn on the Gonski reforms during the campaign masked some of the details and differences between the main parties. Significantly, the ALP committed to continuing the School Kids Bonus whilst the Coalition pledged to abolish it. The Coalition, with a preference for introducing greater forms of localism, also pledged to establish a \$70-million fund to encourage state schools to become independent, along with a commitment to review the curriculum - in effect seeking to relaunch the so-called 'history wars' that characterised the Howard era (Blake 2013). It was also clear that, despite the rhetoric, the ALP was only partially meeting the full suite of Gonski 
recommendations (Caro 2013); some see the period as one in which education policies continued to be shaped by neoliberal priorities, albeit mixed with some social democratic and equity effort (Watson and Liu 2014).

\section{Bipartisanship over disability policy}

Disability policy did not feature as prominently as education policy during the election campaign. To a large extent, the issue had been de-politicised when both the major parties pledged to support the introduction of the ALP's NDIS, which was the outcome of well-organised and well-articulated advocacy over a long period of time (Steketee 2013). Enjoying widespread support across the Australian public, it was a key policy area where Abbott had departed from his usually stronger oppositional stances. This meant that, by the time of the election campaign, the scheme had bipartisan support and both parties were committed to rolling out pilot schemes throughout the nation. The model of NDIS broadly fitted with the recommendations arising from the Productivity Commission's reforms to improve support for people with disabilities. The Coalition's endorsement of the NDIS reflected its commitment and was less of a tactical ploy than its response to the Gonski recommendations.

Yet, throughout the campaign there were some issues arising with the disability scheme. There had been some disquiet in the wider disability community services sector when NDIS was renamed DisabilityCare Australia in March 2013, and the Coalition committed itself to reverting back to the original NDIS (AAP 2013b). There was also a wider debate about how the disability scheme (along with other increased spending proposals such as Gonski) would be funded. Demographer Bernard Salt suggested that unless tax revenues increased the quality of public services might suffer (Mitchell 2013), and the CEO of the Business Council of Australia accused the parties of 'jumping the gun' on financing the scheme (Carswell 2013).

The most damaging aspect of the DisabilityCare reforms for the ALP was in respect to negotiations and dealings with state governments over the roll-out of pilot schemes. To the dismay of Barry O'Farrell in New South Wales, the ALP announced, without consultation, 11 sites for the disability scheme rollout. The New South Wales disabilities minister accused Labor of seeking 'political gain' in their announcement, suggesting that the pilots were in key marginal seats and the timing was designed to maximise another of Labor's flagship policy areas (AAP 2013c). The accusation of politicisation was also made when Labor announced the seven pilots in Queensland, with the state minister claiming to have learned of the sites only via Labor's press release. Significantly, the last state to sign up to the DisabilityCare package was Western Australia. Interestingly, 
the Western Australian Government runs a well-regarded scheme called 'My Way' and the subsequent deal brokered with the federal Government meant that the schemes would run alongside each other, providing fruitful comparison. Overall, Labor's lack of negotiating finesse with the state governments meant that its flagship policy was somewhat tarred, and the broad bipartisan support meant that it had limited scope to draw policy advantage over the Coalition. Disability, like schools education, was successfully neutralised by the Coalition.

\section{Outflanked on the left over paid parental leave?}

If there was broad policy consensus on disability and education, the issue of paid parental leave (PPL) was far more divisive. Historically, Australia has been one of the few remaining advanced industrial nations without such a scheme, although during the Howard era the universal cash 'baby bonus' was the main policy response (Ray, Gornick and Schmitt 2009). Following an inquiry by the Productivity Commission, the Gillard Government had introduced a PPL scheme paid at the minimum wage for 18 weeks whether or not the parent was in the workforce (Productivity Commission 2009). Labor had also promised to increase wages for child care workers, and to scrap the baby bonus and replace it with a $\$ 2,000$ supplement to Family Tax Benefit A.

To some surprise, at Abbott's insistence the Coalition retained the 'signature policy' it took to the 2010 election offering a far more generous scheme than the ALP, promising women their full salary for 26 weeks capped at $\$ 75,000$. Women earning over $\$ 150,000$ would still receive the capped benefit but women not in the workforce would not. Abbott's scheme was to be funded by a 1.5 per cent levy on the top 3,000 companies in Australia, although the same companies would be compensated by a reduction in the company tax rate from 30 to 28.5 per cent. In total the scheme was estimated to cost $\$ 5.5$ billion per year (Coorey 2013a). The Western Australian premier, Colin Barnett, was perhaps emblematic of those on the Coalition side who supported the PPL but considered it 'overly generous' (Coorey 2013b). The Coalition scheme was also seen to be at odds with the simultaneous concerns about the overall budget 'crisis' (Coorey and Daley 2013). This was further complicated for the Coalition as it became clear that the levy on business would only foot some of the PPL bill, and there was inevitably some vocal concern from the wider business community about the Coalition's scheme (Mitchell 2013). ${ }^{2}$

2 The Greens announced a similar scheme to the Coalition's proposal but capped theirs at $\$ 100,000$. 
Not surprisingly, this policy, more than any other social policy issue, dominated the public debate, and Figure 2 gives some impression of how the issue dominated media coverage, when compared to other key social policy issues.

Number of media articles per week by policy area

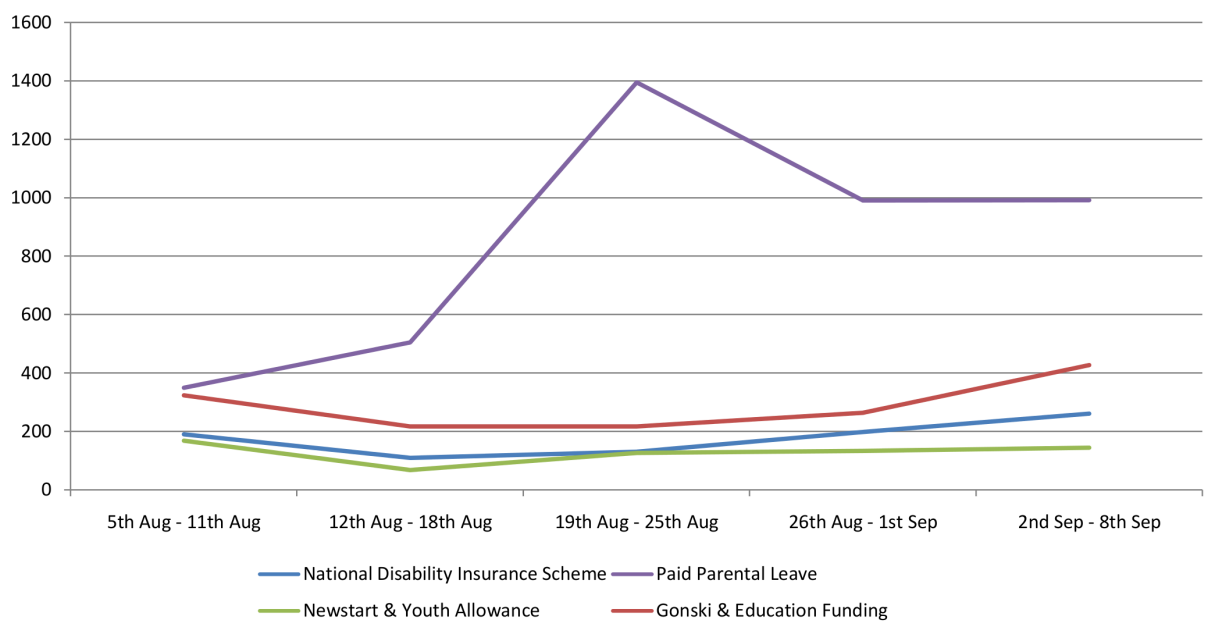

Figure 2: Social policy media articles (5 August to 8 September 2013)

Source: Factiva. Data extracted 11 November 2013.

The arguments between the major parties over their rival PPL schemes raised wider ideological and policy issues. The parties made competing claims about the types of equity being offered in the different schemes, and how low-paid families would fare, especially as the cash baby bonus was abolished. The PPL also raised critical issues about gender, employment and work-life issues, and elicited feminist (and other) responses, notably when public intellectual Eva Cox supported Abbott's scheme as a workplace entitlement (Karvelas 2013a). In many respects, the Coalition seemed to outflank Labor from both the left and the right on this issue. With the support of some feminists, the Coalition's more generous scheme for working women resembled similar Scandinavian social democratic models. Yet, there was also a strong argument that this scheme was an important aspect of both Tony Abbott's conservative thinking and his campaign strategy. Using the government to protect the family unit economically at this time of need was an expression of state activism and a deliberate attempt to deal with Abbott's so-called 'women problem'. Abbott mostly faced criticism from both classical liberals and conservatives within his party who prefer a small state and fiscal constraint (Coorey and Heath 2013).

Some commentators argued that the debate over the PPL displayed some old fashioned 'class warfare' between the parties. During the campaign, Rudd 
described it as a 'dog of a policy' in that it would penalise self-funded retirees and their superannuation savings. Labor, caught mainly on the back foot, raised the spectre that a Coalition Government would be forced to raise the GST to fully fund the scheme - an initial scare tactic which failed to take hold (Coorey and Daley 2013). Accordingly, in a social policy area that should have benefitted the Labor Government, and indeed where the ALP had arguably led the Coalition, they were out-manoeuvred by Abbott's PPL scheme.

\section{Indigenous social policy}

Indigenous policy is an area of continuing controversy and change, and indeed turbulence. In recent times, the Howard Government's Northern Territory Intervention, Rudd's apology to the Stolen Generations, and the Rudd-Gillard Closing the Gap strategies have been the dominant national initiatives in this area. The 'intervention' and 'closing the gap' policy approaches have had a reasonably close association, with the former commencing in 2005 and the second developed over 2006-07 and adopted by the Council of Australian Governments (COAG) in December 2007. There have been some elements of bipartisan consensus in recent national policy approaches, particularly in the Rudd-Gillard acceptance of key elements of the intervention about welfare quarantining whilst pursuing higher levels of housing and related investment through 'closing the gap' policies, an approach shaped through Indigenous Affairs Minister Jenny Macklin's leadership (Karvelas 2013b).

Contemporary indigenous policy is an area of vigorous exchange between advocates. Noel Pearson and Marcia Langton have a strong presence in the debates. Pearson advocates the idea of a 'radical centre' which reconciles liberal, conservative and progressive principles. Pearson's approach brings together Amartya Sen's capability and 'development as freedom' ideas, conservative critiques of passive welfare, and liberal views about the importance of education and mainstream economic participation of indigenous people. This remains perhaps the most dominant framework shaping the public debate about indigenous issues. Nevertheless, other views also have a strong presence in indigenous debates (Altman and Kerins 2012). Some argue that the whole area is powerfully shaped by neoliberal precepts and priorities (Altman 2014). There is also an ongoing division of opinion about the assumptions and impacts of the 'intervention' and the 'closing the gap' strategies. The strong 'advocacy' voice of Murdoch's Australian newspaper in commentary and analysis of indigenous policy, including reinforcing and publishing Pearson's views and supporting the 'intervention', should also be noted. 
Indigenous issues had some presence in the 2013 election campaign. In the leadup to the campaign, some commentators highlighted the ongoing difficulties and failures in dealing with indigenous disadvantage and development, particularly in remote Australia. According to one commentator, land reform, welfare, education and the impact of alcohol abuse in remote indigenous communities were 'the four chief areas of crisis and systemic policy failure bedevilling the indigenous societies of the inland and the north', suggesting that these issues needed further attention in the election campaign (Rothwell 2013a).

Tony Abbott's speech in federal parliament in February 2013 on indigenous recognition was significant in giving some indication about future indigenous policy. In a major shift from recent Coalition stances on reconciliation with indigenous people, particularly under John Howard, Abbott's speech noted the past injustices done to indigenous peoples and the importance of Paul Keating's Redfern speech, and defended the need for constitutional recognition of Aboriginal people. In March, Abbott announced that he would become the 'Prime Minister for Indigenous Affairs' and his February speech was seen by some as providing the 'moral framework' for his leadership in this area (Manne 2013).

Some fundamentals in indigenous policy were debated as the election campaign unfolded. Some commentators associated with Howard's previous policies highlighted the ongoing failures of passive welfare and the excessive bureaucracy associated with the 'intervention'. For instance, Peter Shergold (2013) argued that 'diversity, choice and flexibility' in policy design have been ignored. Indigenous advocates such as Noel Pearson (2013a and 2013b) agreed with these assessments, highlighting the need for indigenous leadership and ownership as a condition of policy success.

By mid-August, the policy positions of the major parties were clearer. In launching the Coalition's policy, Abbott highlighted the continuing crisis in remote indigenous communities and the need for policy reform to be taking 'reconciliation to a new level and embedding the idea of personal responsibility' (Shanahan and Karvelas 2013). He committed to establishing a new indigenous advisory board under the leadership of former ALP president Warren Mundine, which would rationalise bureaucracy and priority-setting in the indigenous area. Abbott spoke of Noel Pearson's leadership and influence on his thinking. He committed to expanding the Pearson/Cape York 'empowered community' approach in indigenous policy (AAP 2013c; Karvelas and Kelly 2013). Some journalists suggested Abbott's approach lacked clarity about where ultimate responsibility for indigenous policy would lie (Rothwell 2013b). For his part, Pearson supported Abbott's plans for constitutional recognition of indigenous peoples, arguing that 'only a highly conservative leader can deliver change' in this area given the difficult history of change through referenda in Australia (Karvelas 2013c). 
On the Labor side, Rudd made the case for greater bipartisanship in indigenous policy, highlighting the need for a more apolitical approach. The Minister for Indigenous Affairs, Jenny Macklin, put the case for new 'closing the gap' targets for indigenous incarceration, participation in higher education and coverage of disabled indigenous people by DisabilityCare Australia (AAP 2013b; Karvelas 2013d). In contrast to the Coalition, the ALP's policies were not all that inspiring and could be viewed as incremental additions to existing unproven policies. Key indigenous leaders, some with previously strong Labor connections, were now in the Coalition circle and the Abbott policies on reconciliation and recognition had a greater freshness and energy, even if there were doubts about a Coalition government's longer-term commitment to them (Strakosch 2013). Immediately post-election, some commentators argued that while the difficulties remained great, Abbott's quest for a new indigenous compact giving emphasis to Pearson's views represented the best hope (Rothwell 2013c). In the event, the Coalition's and Abbott's capacity to develop an indigenous agenda integrating liberal, communitarian and conservative perspectives during the election campaign trumped Labor's more traditional social democratic policy model.

\section{Accommodation in health policy}

The Coalition's attempts to neutralise contentious social policy issues were particularly evident in the area of health policy. Both sides had gradually come to an accommodation over Medicare, bulk-billing, improving the performance of public hospitals, and urging the privatisation of health care via private health insurance. Both major parties supported the existing public/private mix with a strong private insurance scheme and private providers operating alongside Medicare and the public hospital system. This mix pays insufficient attention to equity impacts and social needs and tends to favour the private sector (Lewis 2010; Baum and Dwyer 2014). Hence, for the first time since the 1940s, health was a low-key issue during the 2013 election campaign and, for some, it was the 'missing election debate' (Russell 2013). No significant new policies were announced and, instead of presenting competing health programs, both major parties supported the status quo. This was a very marked change from the vehement disagreements that produced radical policy changes over previous decades. In 2013, Labor was content to run on its record while the Coalition quickly retreated from any proposition that might become controversial. Only the Greens proposed major reforms, drawing attention to some of the structural problems of the system. Greens ideas, however, never reached centre stage, so the major parties were able to slip through the campaign, avoiding issues that might offend major interest groups and sidestepping the concerns of community members and health experts. 
One acknowledged health expert described health policy during the 2013 campaign as 'anodyne, soporific and vapid' (Duckett 2013). Abbott, for his part, said very little about health in his campaign launch speech (Abbott 2013), while Rudd made only a few scattered references. Labor's promise to restore the Commonwealth's share of hospital funding to 50 per cent was a major new commitment (Rudd 2013), although neither side was prepared to address the issue of health spending increasing at a rate faster than GDP growth (AIHW 2013a: 6-7). Other promises were either too broad to be meaningful or were trivial in terms of policy contours.

The health debate between Minister Tanya Plibersek and Shadow Minister Peter Dutton revealed little about party intentions. Both agreed on the importance of Medicare and a strong private health sector. The Coalition announced it would retain Labor's National Health Reform Agreement with the states and territories, through which the Commonwealth's share of hospital funding would ostensibly be increased.

Although critical of 'unnecessary bureaucracy', the Coalition avoided comment on the future of Labor's new national agencies. Both parties promised to fund new cancer care programs and both expressed support for medical research and for the improvement of Aboriginal health. In mental health, both promised small additional pots of funding, seen as a missed opportunity by the sector (Hickey 2013). Mr Abbott committed to maintaining the overall level of hospital and medical funding and to retaining Labor's \$4 billion dental package for children and low income adults, due to begin in 2014. The Greens called for universal primary dental care under Medicare but the proposal attracted little attention.

Labor promised to continue its reform agenda if re-elected. The main RuddGillard structural initiative had been the introduction of Medicare Locals: primary health care organisations charged with planning and coordinating improved primary health care for designated populations, with supporting providers to improve services and fill gaps. The Coalition's initial plan to abolish them gave way during the campaign to a commitment to review them and, finally, to a promise that none would be closed. The closest that party competition came to emerging was when Abbott promised to restore universal eligibility to public subsidy for private insurance which Labor had means-tested.

On the whole, then, bipartisanship in health prevailed, allowing the major parties to ignore the problems that consumers, the Greens and reform groups have identified (such as over-reliance on fee-for-service, user-charging for patients, over-servicing by hospitals, and an under investment in primary health care and preventative care - see AIHW 2013b: 133; Commonwealth of Australia 2009a: 51, 102-4; Gray 2009: 66-76; Gray Jamieson 2012: 317; Elshaug et al. 2012). 


\section{Conclusion}

By astutely adopting a strategy of accommodation over a number of social policy issues, the Coalition was able to neutralise them as issues that could play to Labor's strengths. The Coalition thereby ensured that the main focus of the election campaign remained on fiscal and economic policies and their critique of the Government's (mis)management. Despite some attempts to reframe its social policy agenda, Labor was unable to campaign effectively on what have traditionally been seen as its 'natural' areas of policy strength. Labor attempted to resuscitate policy differences tangentially by claiming that the Coalition's budgetary cuts would disproportionately fall in the education, health and social policy areas. The Coalition effectively countered this argument once Abbott gave an undertaking to quarantine these areas from the cuts, retaining Commonwealth spending at existing levels. And Labor may have undermined its own case because it was already making cuts to public services as a result of its own budgetary difficulties.

\section{References}

Abbott, Tony, 2013. 'Tony Abbott's campaign launch speech: full transcript'. 25 August, viewed 5 November 2013: <www.smh.com.au/federal-politics/ federal-election-2013/tony-abbotts-campaign-launch-speech-full-transcript20130825-2sjhc.html>.

AIHW. 2013a. Health Expenditure Australia 2011-12. Health and Welfare Expenditure Series, Number 50, viewed 5 November 2013: <www.aihw.gov. au/publication-detail/?id=60129544658 $>$.

AIHW. 2013b. Australian Hospital Statistics 2011-12. Health Services Series Number 50, viewed 5 November 2013: <www.aihw.gov.au/WorkArea/ DownloadAsset.aspx ?id $=60129543146>$.

Altman, Jon. 2014. 'Indigenous policy: Canberra consensus on a neoliberal project of improvement'. In Chris Miller and Lionel Orchard (eds), Australian Public Policy: Progressive Ideas in the Neoliberal Ascendency, Bristol: Policy Press.

Altman, Jon and Kerins, Sean (eds). 2012. People on Country: Vital Landscapes, Indigenous Futures. Sydney: Federation Press.

Ashenden, Dean. 2013. 'The Grattan line'. Inside Story, 2 July, viewed 16 July 2014: <inside.org.au/the-grattan-line/>. 
Australian Associated Press (AAP). 2013a. 'Abbott scared of schools backlash: Shorten'. 2 August.

AAP. 2013b. 'FED: Make indigenous policy bipartisan: Rudd'. 10 August.

AAP. 2013c. 'FED: Abbott speaks about his indigenous journey'. 10 August.

AAP. 2013d. 'FED: Open to dump DisabilityCare name'. 20 August.

AAP. 2013e. 'O'Farrell upset over Labor's NDIS plan'. 28 August.

Australian Broadcasting Corporation (ABC). 2012. 'What's in the Gonski report?'. $A B C, 27$ August, viewed 5 November 2013: <www.abc.net.au/news/201208-27/whats-in-the-gonski-report/4219508>.

ABC. 2013. 'Kevin Rudd aims to "forge consensus" in politics after victory over Julia Gillard'. $A B C, 27$ June, viewed 5 November 2013: <www.abc.net.au/ news/2013-06-27/kevin-rudd-responds-to-leadership-win/4784040>.

Baum, Fran and Dwyer, Judith. 2014. 'The accidental logic of health policy in Australia'. In Chris Miller and Lionel Orchard (eds), Australian Public Policy: Progressive Ideas in the Neoliberal Ascendency, Bristol: Policy Press.

Bean, Clive S and McAllister, Ian. 2012. 'Electoral behaviour in the 2010 Australian federal election'. In Marian Simms and John Wanna (eds), Julia 2010: The Caretaker Election, Canberra: ANU E-Press.

Bean, Clive, McAllister, Ian, Pietsch, Juliet and Gibson, Rachel. 2014. Australian Election Study, 2013. Canberra: The Australian Data Archive, The Australian National University.

Blake, Sarah. 2013, 'Policies on education a major battleground'. Adelaide Advertiser, 6 September.

Caro, Jane. 2013. 'Getting past Gonski: school equity beyond the election'. The Conversation, 5 September, viewed 13 January 2014: <theconversation.com/ getting-past-gonski-school-equity-beyond-the-election-17467>.

Carswell, Andrew. 2013. 'NDISaster as Costs Soar'. Daily Telegraph, 5 August.

Commonwealth of Australia. 2009a. A healthy future for all Australians. Final Report of the National Health and Hospitals Reform Commission, Canberra, June.

Commonwealth of Australia. 2009b. Australia: the healthiest country by 2020. Report of the National Preventive Health Task Force, Canberra, 30 June. 
Coorey, Phillip. 2013a. 'Abbott's \$5.5bn baby bill'. Australian Financial Review, 19 August.

Coorey, Phillip. 2013b. 'Critics fear scheme cost blowouts'. Australian Financial Review, 21 August.

Coorey, Phillip and Daley, Gemma. 2013. 'Row over GST, parental leave'. Australian Financial Review, 8 August.

Coorey, Phillip and Heath, Joanna. 2013. 'Abbott dismisses criticism of paid parental leave'. Australian Financial Review, 6 May, viewed 14 February 2014: <www.afr.com/p/national/drop_abbott_paid_parental_leave_ otoRi9yP6nejlpkwnHEfVJ $>$.

Downs, Anthony. 1972. 'Up and down with ecology: The issue attention cycle'. Public Interest 28(1): 38-50.

Duckett, Stephen. 2013. 'Bland is best? Bipartisan health platform left no room for policy'. The Conversation, 10 September, viewed 2 January 2014: $<$ theconversation.com/bland-is-best-bipartisan-health-platform-left-noroom-for-policy-17881>.

Elshaug, Adam, Watt, Amber, Mundy, Linda and Willis, Cameron. 2012. 'Over 150 potentially low value health care practices: an Australian study'. MJA 197(10): 556-60.

Gray, Gwen, 2009. 'Health Policy'. In Dennis Woodward, Andrew Parkin and John Summers (eds), Government, Politics, Power and Policy in Australia, 9th edition, French's Forest, NSW: Pearson.

Gray Jamieson, Gwendolyn. 2012. Reaching for Health, The Australian women's health movement and public policy. Canberra: ANU E-Press.

Hickey, Ian. 2013. 'Mental health is largely missing from the election campaign'. The Conversation, 2 September, viewed 2 January 2014: < theconversation. com/mental-health-is-largely-missing-from-the-election-campaign-17684>.

Karvelas, Patricia. 2010. 'Tony Abbott signs contract on Work Choices but muddles message on workplace laws'. The Australian, 19 July, viewed 21 July 2014: <www.theaustralian.com.au/national-affairs/tony-abbott-signscontract-on-work-choices-but-muddles-message-on-workplace-laws/storyfn59niix-1225893906267>.

Karvelas, Patricia. 2013a. 'Abbott delivers his baby'. The Australian, 21 August.

Karvelas, Patricia. 2013b. 'How Macklin took on the Left to transform indigenous policy'. Weekend Australian, 23-24 November, Inquirer: 15. 
Karvelas, Patricia. 2013d. 'Change needs a conservative: Pearson'. The Australian, 26 August: 1.

Karvelas, Patricia. 2013e. 'Labor commits to new targets to help close indigenous gap'. The Australian, 9 August: 1.

Karvelas, Patricia and Kelly, Paul. 2013. 'Abbott to fund Pearson gap plan'. The Australian, 24 August: 1.

Keating, Jack. 2010. 'Education Policy and Social Inclusion'. In Alison McClelland and Paul Smyth (eds), Social Policy in Australia: Understanding for Action, 2nd edn, Melbourne: Oxford University Press.

Lewis, Jenny. 2010. 'Health Policy: Tackling the Gaps?' In Alison McClelland and Paul Smyth (eds), Social Policy in Australia: Understanding for Action, 2nd edn, Melbourne: Oxford University Press.

Manne, Robert, 2013. 'Lest we forget'. The Monthly 88: 10-4.

McAllister, Ian and Pietsch, Judith. 2011. Trends in Australian political opinion: results from the Australian Election Study, 1987-2010. Canberra: Australian National Institute for Public Policy and ANU College of Arts and Social Sciences.

Mitchell, Sue. 2013. 'Tax base can't support level of services'. Australian Financial Review, 24 August.

Pearson, Noel. 2013a. 'Recent indigenous policy failures can't be pinned on Aborigines'. The Australian, 15 June: 19.

Pearson, Noel. 2013b. 'Yes Minister, we're trapped in bureaucracy'. The Australian, 20 July: 19.

Productivity Commission. 2009. Paid parental Leave: Support for Parents with Newborn Children. Productivity Commission Inquiry report no. 47, February. Canberra: Australian Government.

Ray, Rebecca, Cornick, Janet and Schmitt, John. 2009. 'Parental Leave Policies in 21 Countries: Assessing Generosity and Gender Equality. Washington: Center for Economic and Policy Research.

Rothwell, Nicolas. 2013a. 'The great unmentionables of remote life'. Weekend Australian, 2-3 February, Inquirer: 18.

Rothwell, Nicolas. 2013b. 'Indigenous merry-go-round keeps spinning'. The Australian, 31 August: 21. 
Rothwell, Nicolas. 2013c. 'Abbott's remote chance the best there is'. Weekend Australian, 12-13 October, Inquirer: 17.

Rudd, Kevin. 2013. 'Kevin Rudd's election campaign launch speech, full text'. Guardian Australia, 1 September, viewed 2 January 2014: <theguardian. com/world/2013/sep/01/kevin-rudd-launch-speech-text>.

Russell, Lesley. 2013. 'Health: the missing election debate'. Inside Story, 20 August, viewed 16 July 2014: <inside.org.au/health-the-missing-electiondebate $/>$.

Shanahan, Dennis and Karvelas, Patricia. 2013. 'Abbott: my pledge to close the gap'. The Australian, 10 August: 1.

Shergold, Peter. 2013. 'The best of intentions, the worst of outcomes for indigenous people'. The Australian, 8 June: 19.

Steketee, Mike. 2013. 'How a decades-old proposal became a movement for change'. Inside Story, 22 October, viewed 15 December 2013: <inside.org.au/ national-disability-insurance-scheme/>.

Strakosch, Elizabeth. 2013. 'Will Tony Abbott be a "prime minister for Aboriginal affairs"?'. The Conversation, 11 September, viewed 15 December 2013: <theconversation.com/will-tony-abbott-be-a-prime-minister-foraboriginal-affairs-17985>.

Wanna, John. 2010. 'Business and Unions', in Special Issue: Kevin 07- the 2007 Australian Election, Australian Cultural History, Vol 28 (1), April: 15-22.

Watson, Louise and Liu, Charlotte. 2014. 'Mixed messages in the new politics of education'. In Chris Miller and Lionel Orchard (eds), Australian Public Policy: Progressive Ideas in the Neoliberal Ascendency, Bristol: Policy Press. 
This text taken from Abbott's Gambit: The 2013 Australian Federal Election, edited by Carol Johnson and John Wanna, published 2015 by ANU Press, The Australian National University, Canberra, Australia. 